\title{
Factors Hindering towards Purchase of organic Food Products
}

\author{
Uma.R ${ }^{1}$, Dr.V.Selvam ${ }^{2}$ \\ ${ }^{1}$ (Research Scholar in CommerceSSL,VIT University, Vellore 6320014, Tamil Nadu, India) \\ 2 (Professor of Commerce,SSL, VIT University, Vellore 6320014, Tamil Nadu, India, India)
}

\begin{abstract}
Consumers' food consumption patterns are changing rapidly. Consumers become more concern about the food they consume. They tend to consume foods that are nutritious, healthy, safe and friendly to the environment and animals. With the availability of organic product alternatives at the local super markets the consumers' perception towards healthier eating has been improved. India is best possessed with lot of potential to produce all varieties of organic products due to its various agro climatic regions. In several parts of the country, the inherited tradition of organic farming is an added advantage. This hold promise for the organic producers to tap the market which is growing steadily in the domestic market related to the export market. Currently India ranks $10^{\text {th }}$ among the top ten countries in terms of cultivable land under organic certification. The certified area includes 15\% cultivable area with 0.72 million Hectare and rest $85 \%$ ( 3.99 million Hectare) is forest and wild area for collection of minor forest produces. The total area under organic certification is 4.72 million Hectarein 2013-14.Thus, there is an upward trajectory in the growth of organic agriculture and it became an emerging marketing trend. In today's society, consumers' are educated to choose the food products of their choice keeping in mind about health aspects, nutritional value as important. Thus, there is an increasing demand for organic products in the market. The marketers should increase the supply and availability of the organic food products matching to the demand. But there seems to be a mismatch between the grown of organic food product industry and consumers' desire to buy organic products. In this backdrop, the present empirical research work is an attempt to explore basicallyabout the factors hindering towards purchasing of organic food products in Vellore city, Tamil Nadu, India.
\end{abstract}

Key words: Organic food products, Women perception, Hindering, Agriculture market. Factors Hindering Purchasing of Organic Food Products

\section{INTRODUCTION}

Organic food is becoming more and more popular, as people look for ways to live a healthier, pesticide-free, environmentally friendly, and sustainable lifestyle. Growing interest towards purchasing organic food products is increasing throughout the world. When the organic food movement began, organic farms were relatively small and their products were available mostly in local markets. Since the early 1990's, the interest in organic food has grown at a rate of $20 \%$ per year. Today, organic food is made available in all types of markets. Grocery stores makes up about $3 \%$ of food sales in the U.S. Organic farms use less energy and produces less water than traditional farms. Organic production methods are considered good for the environment, especially since they do not release pesticides into the soil andwater. According to researchers, organic foods are not processed by irradiation, industrial solvents or chemical food stabilizers and do not include any additive ingredients (Allen and Albala,2007). India is one of the countries with largest area under organic management along with Argentina, Brazil, China and Hungary (Willer and Kilcher, 2009). India can be the best potential for the marketers of organic food, but they will have the confidence of the consumers, who are the loyal consumers of organic food, with their quality products (Chakrabarti, 2010). The present empirical study is an attempt to examine the factors hindering towards purchasing of organic food products in Vellore city, Tamil Nadu, India.

\subsection{COST INVOLVED IN PRODUCING ORGANIC FOOD PRODUCTS}

India ranks $10^{\text {th }}$ among the top ten countries in terms of cultivable land under organic certification. The certified area of organic cultivation includes 15\%cultivable area with 0.72 million hectare and rest $85 \%$ is forest and wild area for collection of minor forest products. The following table 1 shows the cost involved in producing organic food products. 
Table 1. Cost involved in producing organic products

\begin{tabular}{|c|c|}
\hline Factors & Estimate \\
\hline Farmer Training & $8-10 \%$ \\
\hline Premium paid to farmers & $10-15 \%$ \\
\hline Processing cost & $4-6 \%$ \\
\hline Inventory holding cost & $6-8 \%$ \\
\hline Logistics and distribution cost & $6 \%$ \\
\hline Packaging cost & $3 \%$ \\
\hline Retailers margin & $12 \%$ \\
\hline
\end{tabular}

Source: secondary data - organic industrial estimate

Factors Hindering Purchasing of Organic Food Products

\section{REVIEW OF LITERATURE}

The literature review prepared for this study on factors hindering towards purchasing of organic food products in India. In order to validate the importance of this study, various literature has been reviewed to identify the statement of problems. Suganya and Aravinth (2015) analysed that consumers avoid using organic products mainly because of price differences existing between organic and non- organic products. Chih-Ching Teng and Yu-Mei Wang (2015) identified that attitude and trust play the mediating roles associating revealed information and perceived knowledge with organic food purchase intention.Umamaheshwari and Chandrasekar (2015) examined that organic products have a paradigm in its awareness and accessibility. Consumers are more aware but they are reluctant due to cost and availability about the range of products. Mohamed Bilal Basha and K. Ramesh (2014) indicated that health concern is the first motivation of organic food consumers chosen for the study and also analysed the impact of demographic variables on the buying intention of consumers of organic products.Ramesh and Divya (2013) have made an interesting observation regarding the main reasons for purchasing of organic food products such as: healthy aspect and environmentally friendly means of production. Justin Paul and Fyoti Rana (2012) analysed that health, availability and education from demographic factors positively influences the consumer's attitudetowards buying organic food.Overall satisfaction of consumers for organic food is more than inorganic food but the satisfaction level varies due to different factors.Zenab sayed saleki and Seyedh Maryam Seyedsaleki (2012) proved that organic culture, environmental concern, price, subjective norms, quality and familiarity affect attitudes and thereby purchasing organic food. Therefore, attitude has mediating role in relationship between the factors and organic purchasing behaviour.Werner and Alvensleben (2011) stated that there is a relationship between the quantity of consumers concern for the environment and their motivation to buy products that are organic. Somnath Chakrabarti (2010) stated that relative importance attached by the experts to key explanatory variables in the consumers' purchase process of organic food. It has attempted to integrate with the relevant recent consumer survey findings and also to highlight the relative importance attached by the experts to key explanatory variables in the consumers' purchase of organic food.Based on the above literature, the study makes further attempt to identify the factors that hinder towards purchasing of organic food products in Vellore city, Tamil Nadu.

\section{STATEMENT OF PROBLEM}

The pesticides contained food products causes several diseases such as: cancer, reproductive dysfunction, diabetes, autism, asthma, birth defects, Parkinson's and Alzheimer's diseases and much more. The organic food has been grown without the use of genetically modified organisms, toxic chemicals, pesticides or fertilizers. The organic food are considered to benatural, safer for the environment and better for consumption. But still consumers are not aware about organic food products.It helps to identify several hindering factors that restrict the consumers towards not purchasing of organic food products. Based on the above various problems expressed and as only less attempt is made in Vellore city, Tamil Nadu. The present research study will certainly fill the research gap to certain extent.

\subsection{OBJECTIVES OF THE STUDY}

Based on the literature review and research gaps identified, the major objectives of the present study are as follows.

1. To study the demographic profile of the respondents.

2. To identify the factors hindering towardspurchasing of organic food products

Factors Hindering Purchasing of Organic Food Product 


\subsection{HYPOTHESIS}

1. Ho1.There is no significant association between income with hindrances of purchasing organic food products

2. Ha1. There is a significant association between income with hindrances of purchasing organic food products.

\subsection{METHODOLOGY OF THE STUDY}

This study is empirical in nature. Both primary and secondary data were collected for the study. Simple random sampling technique was used for the collection of data in Vellore city. A total of 100 samples were collected from the total population. A self-constructed questionnaire was framed and collected through direct survey method.The questionnaire consists of two sections. First section deals with demographic profile and the second section deals with factors hindering towards purchasing of organic food products using five point Likert's scale. SPSS software version 21 was used to analyse the objectives of the study and statistical tools like frequency distribution, Percentage analysis and one way Anova were used to inference the data.

\subsection{LIMITATIONS OF THE STUDY}

The study was conducted only in Vellore city of Tamil Nadu among women and the samplesize was restricted to 100 respondents. The opinion given by the respondents for this study may not be applicable in other cities of India.The researcher collected data by using constructed questionnaire and there is possibility of bias. The period of study is restricted to two months i.e., from August, 2016 to September, 2016.

\section{ANALYSIS AND INTERPRETATION}

\subsection{Demographic profile of the study}

The data pertaining to demographic profile of the respondents were given in table 2.

Table 2. Shows the demographic profile of the respondents

\begin{tabular}{|c|c|c|c|}
\hline Parameters & Category & Frequency & Percentage \\
\hline \multirow[t]{5}{*}{ Age } & 18 to 22 & 18 & 18 \\
\hline & 23 to 27 & 23 & 23 \\
\hline & 28 to 32 & 37 & 37 \\
\hline & 33 to 37 & 10 & 10 \\
\hline & Above 38 & 12 & 12 \\
\hline Total & & 100 & 100 \\
\hline \multirow[t]{5}{*}{ Education } & $10^{\text {th }}$ std & 9 & 9 \\
\hline & +2 & 18 & 18 \\
\hline & Degree & 43 & 43 \\
\hline & Post Graduate & 18 & 18 \\
\hline & Others & 12 & 12 \\
\hline Total & & 100 & 100 \\
\hline \multirow{5}{*}{ Income } & Below Rs.10000 & 34 & 34 \\
\hline & Rs.10000to20000 & 17 & 17 \\
\hline & Rs. 20000 to 30000 & 20 & 20 \\
\hline & Rs. 30000 to 40000 & 15 & 15 \\
\hline & Above Rs.40000 & 14 & 14 \\
\hline Total & & 100 & 100 \\
\hline \multirow[t]{6}{*}{ Occupation } & Housewife & 6 & 6 \\
\hline & Pvt. Employee & 35 & 35 \\
\hline & Govt .Employee & 28 & 28 \\
\hline & Professional & 12 & 12 \\
\hline & Self-employed & 17 & 17 \\
\hline & Others & 2 & 2 \\
\hline Total & & 100 & 100 \\
\hline \multirow[t]{2}{*}{ Marital } & Married & 78 & 78 \\
\hline & Unmarried & 22 & 22 \\
\hline Total & & 100 & 100 \\
\hline
\end{tabular}

Source: Primary data

INFERENCE

From the above table, it is inferred that the majority of the respondents $37 \%$ were in the age groupof 28-32and with regard to education $43 \%$ of the respondents were degree holders.Regarding income, $34 \%$ of the 
respondents belongs to income group below Rs.10000, with regard to occupation, 35\% of the respondents were private employees and $78 \%$ of the respondents were married

\subsection{FACTORS HINDERING TOWARDS PURCHASING ORGANIC FOOD PRODUCTS}

Oneway Anova was applied on the data in order to identify the significant relationship between incomes (dependent variable) with several different parameters (independentvariables) relating to factors hindering towards purchasing of organic food products in Vellore city and the same was presented in table 3.

Table 3. One way Anova

\begin{tabular}{|c|c|c|c|}
\hline \multicolumn{2}{|l|}{ Parameters } & $\mathrm{F}$ & Sig. \\
\hline \multirow[t]{3}{*}{ Distrust } & Between Groups & 5.124 & .184 \\
\hline & Within Groups & & \\
\hline & Total & & \\
\hline \multirow[t]{3}{*}{ Lack of knowledge } & Between Groups & 10.234 & .004 \\
\hline & Within Groups & & \\
\hline & Total & & \\
\hline \multirow[t]{2}{*}{ Unavailability } & $\begin{array}{l}\text { Between Groups } \\
\text { Within Groups }\end{array}$ & & 0.01 \\
\hline & Total & & \\
\hline $\begin{array}{l}\text { Difficult to differentiate } \\
\text { between organic and } \\
\text { conventional food products }\end{array}$ & $\begin{array}{l}\text { Between Groups } \\
\text { Within Groups } \\
\text { Total }\end{array}$ & 5.087 & .003 \\
\hline
\end{tabular}

\begin{tabular}{|l|l|l|l|}
\hline Health Aspect & $\begin{array}{l}\text { Between Groups } \\
\text { Within Groups } \\
\text { Total }\end{array}$ & 10.756 & .000 \\
\hline Flavourless & $\begin{array}{l}\text { Between Groups } \\
\text { Within Groups } \\
\text { Total }\end{array}$ & 10.665 & 0.02 \\
\hline Lacks in variety & $\begin{array}{l}\text { Between Groups } \\
\text { Within Groups } \\
\text { Total }\end{array}$ & 10.787 & 0.00 \\
\hline
\end{tabular}

\section{INFERENCE}

Source: Primary data, Significant at the 5\%

The results of variance analysis (one-way Anova) revel statistically no significant association (null hypothesis is not accepted) between income and all the six variables relating to factors hindering towards purchasing of organic food products such as: Knowledge about organic food food products $(\mathrm{P}$ value $=0.04<$ $0.05)$, Unavailability of organic food store $(\mathrm{P}$ value $=0.01<0.05)$, Difficult to differentiate between organic and non-organic food products $(\mathrm{P}$ value $=0.03<0.05)$, Due to health aspect $(0.00<0.05)$, Flavourless $(\mathrm{P}$ value $=$ $0.02<0.05)$, Lacks in variety $(0.00<0.05)$. Income of the respondents is considered to be influential factor while analysing factors hindering towards purchase of organic food products. And theremaining distrust factor $(\mathrm{P}$ value $=0.184<0.05$ ) shows that income is regarded as an insignificant factor.

\section{CONCLUSION}

To conclude that, this empirical study explains the women perception towards hindrances on buying organic food products and hindering the growth of agricultural market among women in Vellore city. Indiais bestowed with lot of potential to produce all varieties of organic products due to its various agro climatic regions. This holds promise for the organic producers to tap the market which is growing steadily in the domestic market related to the export market. The present study concludes that, though women have intention to purchase organic products but they are reluctant in cost and availability of the products. To conclude this, the organic food products will expand to grow by overcoming the difficulties and also problems on implementing agricultural market in India.

\section{REFERENCES}

[1] Allen and Albala, The Business of Food: Encyclopedia of the Food and Drink Industries, Greenwood Publishing Group, United State of American, 2007,288 
[2] Willer, H. and Kilcher, The World of Organic Agriculture. Statistics and Emerging, IFOAM, 2009, 1-307 Somnath Chakrabarti, Factors influencing organic food purchase in India - expert survey insights, British Food Journal, 112 (8), 2010, 902 - 915

[3] Chih-Ching Teng and Yu-Mei Wang,Decisional factors driving organic food consumption, British Food Journal, 117(3), 2015, 1066-1081.

[4] Mohamed Bilal Basha and Ramesh,Consumer Attitude towards Organic Food in Trichy -South India, International Journal of Marketing and Human Resource Management,5(5), 2014, 01-10.

[5] Somnath Chakrabarti, Factors Influencing Organic Food purchase In India-Expert Survey Insights, British Food Journal, 112(8), 2010, 902-915.

[6] Suganya and Aravinth, Consumers Awareness and Attitude towards Organic Products, Journal of International Academic Research for Multidisciplinary, 1(12), 2014, 738-746.

[7] Umamaheshwari and Chandrasekar, A Study on Consumer Perception and Attitude Towards Organic Products With Reference to Western Districts of TamilNadu, Indian Journal Of Applied Research, 5(4), 2015, 383-387.

[8] Ramesh and Dhivya, A study on consumers' awareness attitude and satisfaction towards select organic foodproducts with reference to Coimbatore, International Journal of Interdisciplinary and Multidisciplinary Studies, International Journal of Interdisciplinary and Multidisciplinary Studies, 2(4), 2015, 81 -84.

[9] Justin Paul, Jyoti Rana,,Consumer behavior and purchase intention for organic food, Journal of Consumer Marketing, 29(6), 2012, 412 - 422

[10] Werner and Alvensleben, Consumer Attitudes towards organic food in Germany(F.R.),'Symposium on Horticultural economics, 8 (155), 2011.

[11] [12]. Zenab sayed saleki and Seyedh Maryam Seyedsaleki, The Main Factors Influencing Purchase Behaviour of Organic Products in Malaysia, Interdisciplinary Journal of Contemporary Research in Business,4(1),2012, 98-116 